\title{
Adrenomedullin and adrenotensin increase the transcription of regulator of G-protein signaling 2 in vascular smooth muscle cells via the cAMP-dependent and PKC pathways
}

\author{
YUANJIE MAO ${ }^{1,2}$, JIALIN SU ${ }^{1,3}$, LEI LEI ${ }^{4}$, LEI MENG ${ }^{1}$, YONGFEN QI $^{1,5}$, YONG HUO $^{1}$ and CHAOSHU TANG ${ }^{1,5}$ \\ ${ }^{1}$ Department of Cardiology, Peking University First Hospital, Beijing 100034, P.R. China; \\ ${ }^{2}$ Department of Biochemistry, National Cerebral and Cardiovascular Center, Suita, Osaka 565-8565, Japan; \\ ${ }^{3}$ Cardiology Division, Cardiovascular Research Center, Rhode Island Hospital and Warren Alpert Medical School of \\ Brown University, Providence, RI 02912, USA; ${ }^{4}$ Department of Endocrinology, Beijing Aerospace Center Hospital, \\ Beijing 100049; ${ }^{5}$ Department of Physiology, School of Basic Medical Sciences, Peking University, Beijing 100083, P.R. China
}

Received April 12, 2013; Accepted October 1, 2013

DOI: $10.3892 / \mathrm{mmr} .2013 .1751$

\begin{abstract}
The regulator of G-protein signaling 2 (RGS2) has been shown to be crucial in the regulation of vascular tone and blood pressure. The vascular activities of adrenomedullin (ADM) and adrenotension (ADT), two natural peptides, are dependent upon the modulation of RGS2 expression. However, the effects and pathways involved in their modulation remain unknown. This study aimed to observe the changes of RGS2 expression in response to ADM and ADT in cultured vascular smooth muscle cells and to clarify the potential signaling pathways in vitro. In the present study, vascular smooth muscle cells (VSMCs) were cultured with ADM and ADT of various concentrations for different time periods, and the gene expression of RGS2 was analyzed by PCR. ADM significantly increased the gene expression at $0.5 \mathrm{~h}$ to $\sim 35$-fold of that at baseline, whereas ADT marginally increased the expression after 1-2 h. SQ22,536 and chelerythrine were used to block the protein kinase A (PKA) and PKC pathways activated by incubation with ADM. The gene expression of RGS2 was reduced by SQ22,536 only. Furthermore, when SQ22,536 and chelerythrine were added to the cells incubated with ADT, the gene expression was markedly reduced by both SQ22,536 and chelerythrine. In conclusion, ADM immediately showed a marked increase in the gene expression of RGS2 in cultured VSMCs via a cAMP-dependent pathway and ADT gradually showed a marginal increase in the gene expression via a cAMP-dependent pathway and a PKC pathway.
\end{abstract}

Correspondence to: Dr Yong Huo, Department of Cardiology, Peking University First Hospital, 8 Xishiku Street, West City, Beijing 100034, P.R. China

E-mail: huoyong@263.net.cn

Key words: adrenomedullin, adrenotensin, regulator of G-protein signaling 2, vascular smooth muscle cells

\section{Introduction}

Vascular tone and blood pressure are regulated by the opposing actions of vasoconstrictor and vasodilator agonists that signal via $G$ protein-coupled receptors (GPCRs) (1). Vasoconstrictors such as angiotensin II, endothelin, vasopressin and norepinephrine bind to their GPCRs and activate heterotrimeric Gq proteins. The $\mathrm{Gq}$ proteins then trigger several responses in vascular smooth muscle cells (VSMCs), including $\mathrm{Ca}^{2+}$ release from intracellular stores and $\mathrm{Ca}^{2+}$ entry through the plasma membrane, which results in myosin light chain phosphorylation and contraction (1).

The duration and intensity of GPCR signaling is modulated by the regulator of $G$ protein signaling (RGS) proteins, which attenuate signaling by stimulating the $G$ protein subunits to hydrolyze guanosine triphosphate, returning them to the inactive guanosine diphosphate-bound state $(2,3)$. RGS2 is one of the predominant RGS proteins in the cardiovascular system and has been shown to be crucial in the regulation of vascular tone and blood pressure. RGS2 deficiency in mice is associated with a hypertensive phenotype and an increased sensitivity, as well as prolonged responsiveness to vasoconstrictors (4-6). In addition, genetic polymorphisms of RGS2 are correlated with hypertension and intima-media thickening of carotid arteries in humans (7-9).

Adrenomedullin (ADM) is a 52 amino acid peptide, which was identified and isolated from human pheochromocytoma extracts (10). Two hallmark actions of ADM, hypotension and diuresis, suggest that it is important in vascular tone regulation (11). Intravenous infusion of ADM has been demonstrated to result in prolonged hypotension in cats, rats, rabbits, sheep and humans (12-21). ADM is derived from a larger precursor molecule, proADM (22). ProADM is cleaved by endogenous peptidases into 4 bioactive peptides: PreproADM22-41, preproADM45-92, preproADM95-146 (ADM) and preproADM153-185(23). These peptidases exhibit different roles in physiological processes; the effects of preproADM22-41 are similar to that of ADM (24), while PreproADM153-185 leads to marked contractile activity 
in cat pulmonary arterial rings and is termed adrenotensin (ADT) (25). ADT acts in a modulatory manner to influence vasorelaxation in response to ADM (26). There appears to be complex interactions (antagonism or synergism in vascular activities) between ADM and ADT, and these interactions may be active in the regulation of circulatory homeostasis (26).

As GPCR ligands, the vascular activities of ADM and ADT depend on the modulation of RGS2 expression. However, the effects and pathways of their modulation remain unknown. This study aimed to observe the changes of RGS2 expression in response to ADM and ADT in cultured VSMCs and to clarify the potential signaling pathways in vitro.

\section{Materials and methods}

Animals. Four male Wistar rats (age, 8 weeks) purchased from the Institute of Laboratory Animal Science, Chinese Academy of Medical Sciences (Beijing, China), were sacrificed by intravenous administration of overdosed pentobarbital. The segment of thoracic aorta between the left subclavian and subcostal arteries was removed for VSMC isolation using enzymatic digestion, as previously described (27). This study was conducted in accordance with the guidelines of Peking University First Hospital and recommendations for the care and use of laboratory animals of the Chinese Ministry of Agriculture.

Cell culture. Cells were grown in Dulbecco's modified Eagle's medium (Sigma-Aldrich, St. Louis, MO, USA) supplemented with $10 \%$ fetal bovine serum (HyClone Laboratories Inc., Logan, UT, USA), penicillin (100 U/ml; Invitrogen Life Technologies, Carlsbad, CA, USA) and streptomycin $\left(100 \mu \mathrm{g} / \mathrm{ml}\right.$, Invitrogen Life Technologies) at $37^{\circ} \mathrm{C}$ in a humidified incubator in a $5 \% \mathrm{CO}_{2}$ atmosphere. Only VSMCs from the third to sixth cell passage were used. The cells were then cultured in six-well, collagen I-coated BioFlex plates containing a flexible silicone elastomer substratum (Flexcell International, Hillsborough, NC, USA).

Drugs. Angiotensin II (002-12), ADM (010-08), and adrenotensin (010-07) were purchased from Phoenix PharmaLabs, Inc. (Shanghai, China). Forskolin (66575-29-9), SQ22,536 (17318-31-9) and chelerythrine chloride (3895-92-9) were purchased from Sigma-Aldrich.

Incubation with cultured cells. Following replacement of the collagen-coated BioFlex plates with serum-free medium for $24 \mathrm{~h}$, cells achieved $70 \%$ confluence and were subjected to incubation with vehicle, ADM, ADT or angiotensin II for different time periods $\left(10^{-7} \mathrm{~mol} / 1\right.$ for $0,0.5,1,2$ or $\left.4 \mathrm{~h}\right)$ or at different concentrations $\left(10^{-9}, 10^{-8}\right.$ and $10^{-7} \mathrm{~mol} / \mathrm{l} \mathrm{ADM}$ for $0.5 \mathrm{~h}$ and ADT for $1 \mathrm{~h}$ ). The cultured VSMCs were also incubated with forskolin $\left(10^{-5} \mathrm{~mol} / \mathrm{l}\right)$, a PKA pathway agonist, for different time periods $(0,0.5,1,2$ or $4 \mathrm{~h})$. SQ22,536 $\left(10^{-4} \mathrm{~mol} / \mathrm{l}\right)$ and chelerythrine $\left(10^{-6} \mathrm{~mol} / \mathrm{l}\right)$ were used to block the PKA pathway and PKC pathways by co-incubation with vehicle or ADM for $0.5 \mathrm{~h}$ and vehicle or ADT for $1 \mathrm{~h}$. Subsequent to this, the gene expression of RGS2 was analyzed by PCR.
Gene expression. Total RNA was extracted from the cultured cells using TRIzol (Life Technologies Co., Gaithersburg, MD, USA). qPCR was performed using a Toyobo ReverTra Ace- $\alpha-{ }^{\circledR}$ RT-PCR kit (Toyobo Life Science, Osaka, Japan). The expression of selected mRNAs was measured by qPCR using the ABI Prism 7700 Sequence Detector (Life Technologies). Expression of the mRNAs was normalized to that of the corresponding $\beta$-actin mRNA. PCR reactions were performed in $25 \mu \mathrm{l}$ buffer containing $1 \mu \mathrm{l}$ cDNA, SYBR-Green Master mix (Life Technologies) and 5 pmol sequence-specific primers: Forward: 5'-CTG CGT ACC CAT GGA CAA GA-3' and reverse: 5'-TTG GGC TTC CCA GGA GTA GA-3' for RGS2; and forward: 5'-AGG CCA ACC GTG AAA AGA TG-3' and reverse: 5'-ACC AGA GGC ATA CAG GGA CAA-3' for $\beta$-actin. Thermal cycling conditions consisted of a preincubation step for $2 \mathrm{~min}$ at $50^{\circ} \mathrm{C}$, denaturation for $10 \mathrm{~min}$ at $95^{\circ} \mathrm{C}$ followed by 40 cycles of denaturation for $15 \mathrm{sec}$ at $95^{\circ} \mathrm{C}$ and annealing/extension for $1 \mathrm{~min}$ at $60^{\circ} \mathrm{C}$. qPCR reactions were performed in triplicate.

Statistical analysis. Values were expressed as the mean \pm standard error of the mean. Statistical differences between groups were determined by either one-way or two-way analysis of variance. When a statistical difference was detected, Tukey's method of adjustment was used for multiple pairwise comparisons. $\mathrm{P}<0.05$ was considered to indicate a statistically significant difference.

\section{Results}

ADM increases RGS2 in a time- and concentration-dependent manner. Following incubation with ADM $\left(10^{-7} \mathrm{~mol} / \mathrm{l}\right)$, the gene expression of RGS2 was significantly increased at $0.5 \mathrm{~h}$, reaching a peak $\sim 35$ fold of that at baseline and gradually decreasing to 2 -fold that of baseline at $4 \mathrm{~h}$ $(\mathrm{P}<0.05)$. When incubated for $0.5 \mathrm{~h}$ with different concentrations of ADM, ADM at concentrations of $10^{-8}$ and $10^{-7} \mathrm{~mol} / 1$ significantly increased the gene expression of RGS2 $(\mathrm{P}<0.05$; Fig. 1).

ADT increases RGS2 in a time and concentration-dependent manner. Following incubation with ADT $\left(10^{-7} \mathrm{~mol} / \mathrm{l}\right)$ the gene expression of RGS2 was significantly increased to $\sim 3$.7-fold of that at baseline after $1 \mathrm{~h}(\mathrm{P}<0.05)$. Subsequent to incubation for $1 \mathrm{~h}$ with different concentrations of ADT, a concentration of $10^{-7} \mathrm{~mol} / \mathrm{l}$ significantly increased the gene expression of RGS2 ( $\mathrm{P}<0.05$; Fig. 2). The expression of RGS2 was also significantly increased by angiotensin II incubation $\left(10^{-7} \mathrm{~mol} / \mathrm{l}\right)$ to $\sim 2.5$-fold of that at baseline at $2 \mathrm{~h}(\mathrm{P}<0.05$; Fig. 2$)$.

Effects of signaling reagents. Forskolin $\left(10^{-5} \mathrm{~mol} / \mathrm{l}\right)$, a cyclic adenosine monophosphate (cAMP)-dependent pathway agonist, significantly increased the gene expression of RGS2 at $0.5 \mathrm{~h}$ to a peak of $\sim 30$-fold of that at baseline $(\mathrm{P}<0.05)$, which then gradually decreased to $\sim 5$-fold of that at baseline at $4 \mathrm{~h}$. When the PKA pathway antagonist SQ22,536 $\left(10^{-4} \mathrm{~mol} / \mathrm{l}\right)$ and PKC inhibitor chelerythrine $\left(10^{-6} \mathrm{~mol} / \mathrm{l}\right)$ was incubated with the cells treated with ADM $\left(10^{-7} \mathrm{~mol} / \mathrm{l}\right)$, the gene expression of RGS2 was markedly reduced by SQ22,536 only. Moreover, when SQ22,536 and chelerythrine 

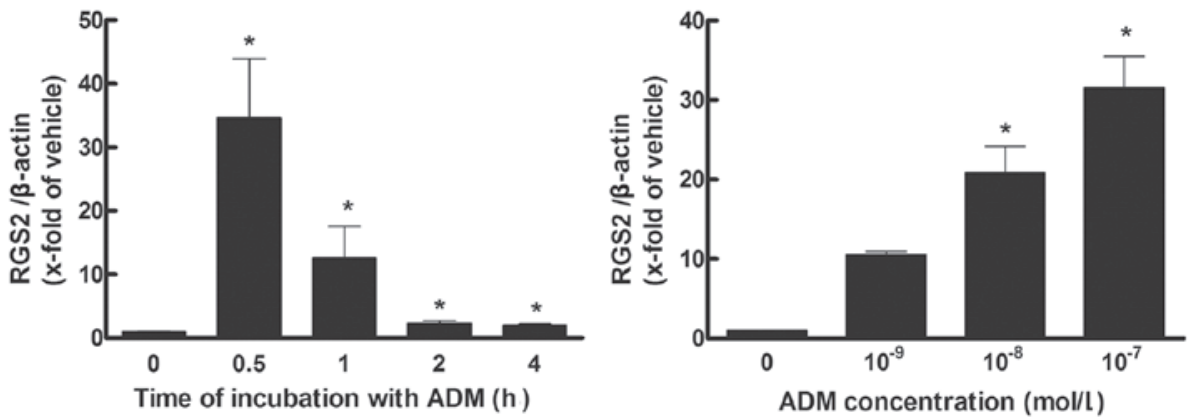

Figure 1. Adrenomedullin (ADM) increased the regulator of G-protein signal 2 (RGS2) transcription, expressed as the transcription ratio of RGS2 to $\beta$-actin, in cultured vascular smooth muscle cells. The RGS2 transcription was measured in the presence of adrenomedullin $\left(10^{-7} \mathrm{~mol} / 1\right)$ or vehicle at $0,0.5,1,2$ and $4 \mathrm{~h}$ (data were normalized with that of vehicle) or at concentrations of $0,10^{-9}, 10^{-8}$ and $10^{-7} \mathrm{~mol} / 1$ for $0.5 \mathrm{~h}$. Data are presented as the mean $\pm \mathrm{SEM}$; $\mathrm{n}=6 \mathrm{in}$ each group; ${ }^{*} \mathrm{P}<0.05$ vs.either $0 \mathrm{~h}$ ADM incubation or $0 \mathrm{~mol} / \mathrm{l} \mathrm{ADM}$.

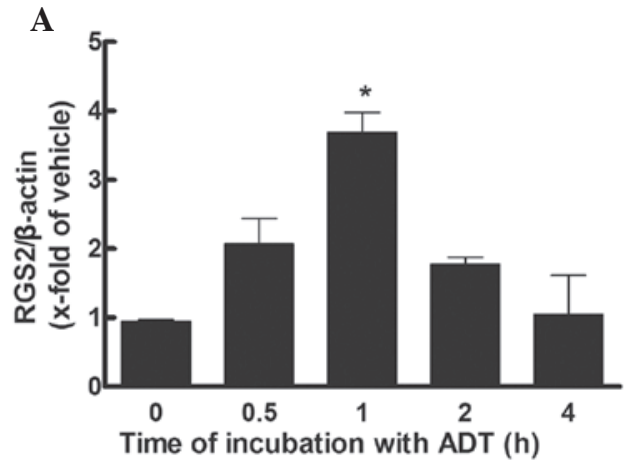

B

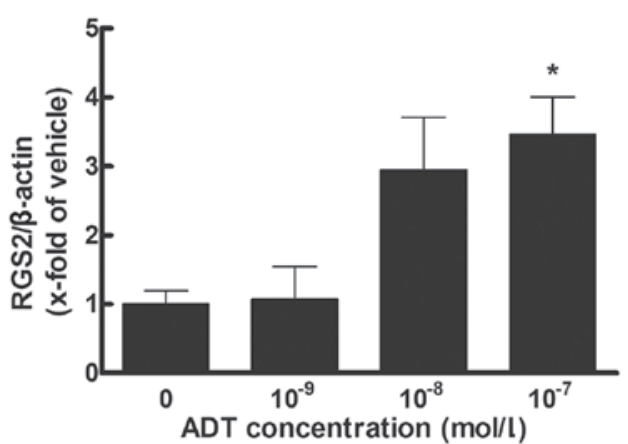

C

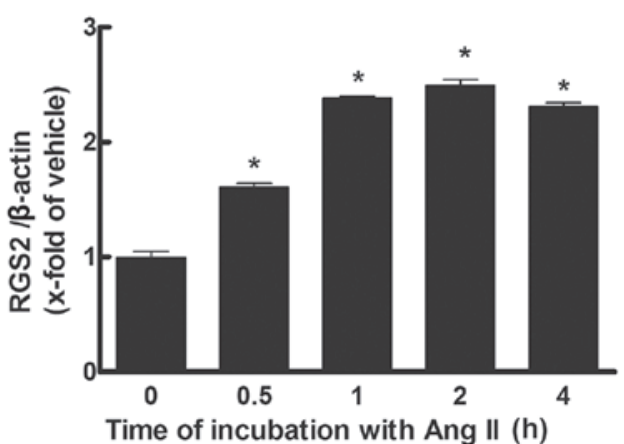

Figure 2. Adrenotensin (ADT) and angiotensin II (Ang II) increased the regulator of G-protein signal 2 (RGS2) transcription, expressed as the transcription ratio of RGS2 to $\beta$-actin, in cultured vascular smooth muscle cells. RGS2 transcription was measured in the presence of (A) adrenotensin $\left(10^{-7} \mathrm{~mol} / \mathrm{l}\right)$ or $(\mathrm{C})$ angiotensin II $\left(10^{-7} \mathrm{~mol} / \mathrm{l}\right)$ and vehicle at $0,0.5,1,2$ and $4 \mathrm{~h}$ (data were normalized with vehicle) or (B) at concentrations of $0,10^{-9}, 10^{-8}$, and $10^{-7} \mathrm{~mol} / 1$ for $1 \mathrm{~h}$. The results are presented as the mean $\pm \mathrm{SEM} ; \mathrm{n}=6$ per group; ${ }^{*} \mathrm{P}<0.05$ vs. either $0 \mathrm{~h}$ ADM incubation or $0 \mathrm{~mol} / \mathrm{l} \mathrm{ADM}$.

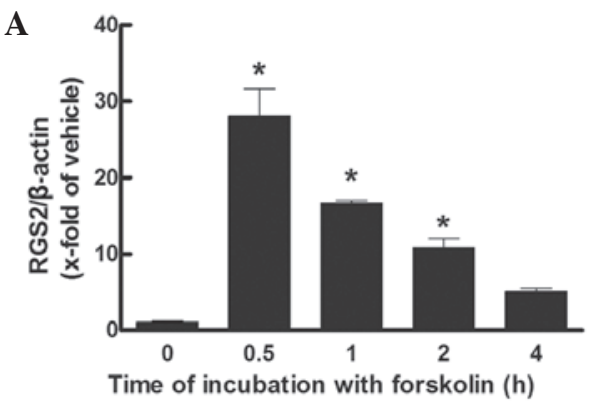

B

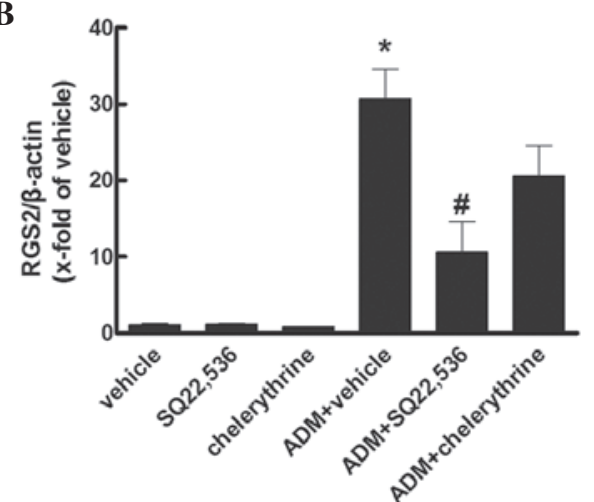

$\mathbf{C}$

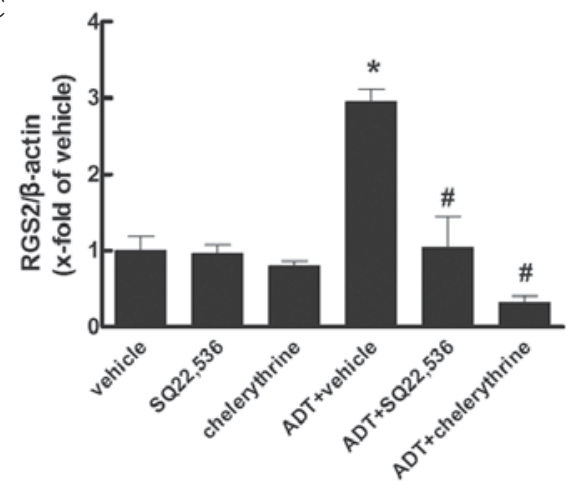

Figure 3. The effects of signaling reagents on the regulator of G-protein signal 2 (RGS2) transcription, expressed as the transcription ratio of RGS2 to $\beta$-actin, in cultured vascular smooth muscle cells. RGS2 transcription was measured (A) in the presence of forskolin $\left(10^{-5} \mathrm{~mol} / \mathrm{l}\right)$ or vehicle at 0 , $0.5,1,2$, and $4 \mathrm{~h}$ (data were normalized with vehicle), or in the presence of SQ22,536 $\left(10^{-4} \mathrm{~mol} / \mathrm{l}\right)$ or chelerythrine $\left(10^{-6} \mathrm{~mol} / \mathrm{l}\right)$ or vehicle together with (B) adrenomedullin (ADM; $10^{-7} \mathrm{~mol} / 1$ ) for $0.5 \mathrm{~h}$ or with $(\mathrm{C})$ adrenotensin (ADT; $10^{-7} \mathrm{~mol} / \mathrm{l}$ ) for $1 \mathrm{~h}$. The results are presented as the mean $\pm \mathrm{SEM} ; \mathrm{n}=6$ per group; ${ }^{*} \mathrm{P}<0.05$ vs. either $0 \mathrm{~h}(\mathrm{~A})$ or vehicle (B and $\left.\mathrm{C}\right)$; ${ }^{*} \mathrm{P}<0.05$ vs. the adrenomedullin or adrenotensin with vehicle group (B and $\mathrm{C}$ ). 
was incubated with ADT $\left(10^{-7} \mathrm{~mol} / \mathrm{l}\right)$, the gene expression of RGS2 was markedly reduced by SQ22,536 and chelerythrine (P<0.05; Fig. 3).

\section{Discussion}

In the present study, it was demonstrated that the modulation of RGS2 gene expression in cultured VSMCs by ADM and ADT occurs via different pathways. As ADM and ADT are potential vascular therapeutic agents and RGS2 may be used as a future theraputic target for vascular diseases, this study provides additional information for their potential clinical application.

RGS2 has been shown to be crucial in the regulation of vascular tone and hypertension. Haplo-insufficiency or elimination of the RGS2 gene leads to hypertension in mice (6). Certain RGS2 haplotypes also cosegregate with human hypertension (8). Furthermore, RGS2 was shown to selectively inhibit Gq signaling and thereby attenuates the action of vasoconstrictors (28). Aortic rings from RGS2 knockout mice exhibited increased contraction and impaired cyclic guanosine monophosphate (cGMP) mediated relaxation in vitro (4). Previously, it was suggested that RGS2 functions as a novel target or effector of the nitric oxide-cGMP pathway to regulate vasoconstrictor signaling (4). RGS2 mediated the action of the nitric oxide-cGMP pathway in several tissues as it is widely expressed, including in vascular smooth muscle and kidney (29). RGS2 regulates blood pressure to a significant extent by mediating the ability of the nitric oxide-cGMP pathway to relax the resistance vasculature and attenuate vasoconstrictor signaling in VSMCs (5). The short-term action of nitric oxide donor on blood pressure is impaired in RGS2 knockout mice. Furthermore, the loss of RGS2 in primary smooth muscle cells from mesenteric resistance arteries increases the magnitude and duration of agonist-induced $\mathrm{Ca}^{2+}$ responses and blocks the ability of cGMP analogs to attenuate agonist-induced $\mathrm{Ca}^{2+}$ signaling (4).

In the present study, ADM significantly increased the expression of RGS2 mRNA at $0.5 \mathrm{~h}$ to 35 -fold of that at baseline, whereas ADT and angiotensin II marginally increased the expression of RGS2 mRNA after 1-2 $\mathrm{h}$. Therefore, the increased RGS2 expression may be crucial in the vascular activities of ADM and the latent and marginal increase of RGS2 expression following the stimulation of vasoconstrictors such as ADT and Angiotensin II may be a compensated change.

ADM is a potent cardiovascular-active peptide that has hypotensive, natriuretic and diuretic actions. It is considered to be important in the pathophysiology of numerous disorders, such as hypertension, acute coronary syndromes and renal failure (30). It inhibits the angiotensin II-induced proliferation and migration effects on renal mesangial cells and exhibits an anti-oxidant action on these cells (30). ADM was observed to stimulate adenylyl cyclase activity in a platelet bioassay. ADM receptors are coupled to adenylate cyclase via G-proteins and the cyclic ring structure and C-terminal amidation are essential for full binding and activity (10). Moreover, ADM has been demonstrated to activate the adenylate cyclase-cAMP system in isolated cardiac myocytes, which is one of the predominant pathways for the regulation of myocardial contractility (31). In the present study, the effects of ADM on RGS2 expression was simulated by adenylate cyclase activator forskolin and blocked by the adenylate cyclase antagonist SQ22,536. Therefore, the effect of ADM on RGS2 expression occurs via adenylate cyclase and a PKA pathway.

Consistently, the ADM-mediated effects in calcified VSMCs and vitamin D3 plus nicotine-treated aortas were also similar to that of forskolin, while the PKA inhibitor H89 blocked the effect of ADM (32). Furthermore, ADM induced the relaxation of rat brain pericytes, which was associated with the reduced phosphorylation of myosin light chain through the cAMP/PKA signaling pathway. H89 inhibited the ADM-induced increase in the number of relaxed pericytes and returned the phosphorylation of the myosin light chains to that of the control levels (33).

ADT, which is derived from the common precursor of ADM, is also an active peptide. ADT has been demonstrated to produce contractile responses in cat pulmonary arterial rings in a concentration-dependent manner (34). In anesthetized rats, an intravenous bolus injection of ADT increased the mean arterial pressure. In cultured rat vascular smooth muscle cells, $10^{-7} \mathrm{~mol} / \mathrm{l}$ ADT increased 3H-TdR incorporation (26). ADT induced endothelium-dependent vasoconstriction and elevated blood pressure $(25,34)$. Moreover, ADT acts in a modulatory manner to influence vasorelaxation in response to ADM. ADT has been shown to antagonize the stimulatory effect of ADM on endothelial nitric oxide generation (26). ADT also induced an increase in the concentration of medium immunoreactive ADM (35). In a rat model of pulmonary hypertension, ADM and ADT exhibited opposite effects on vasoactivity and showed reciprocal inhibition in their release (36). However, the signaling pathway of ADT remains unclear. The results of the present study showed that SQ22,536 and chelerythrine chloride blocked the effects of ADT on RGS2 expression significantly, which suggest that the effect of ADT on RGS2 expression occurred via a PKA and PKC pathway.

In conclusion, our results showed that ADM immediately exhibited a significantly increased the gene expression of RGS2 in VSMCs via cAMP-dependent pathway and ADT gradually showed a marginal increase in the gene expression of RGS2 via a cAMP-dependent and a PKC pathway. This suggests the different responses of RGS2 to vasodilators and vasoconstrictors.

\section{Acknowledgements}

The authors are grateful to Ms. Lin Xue and Ms. Chunyu Zhao for their technical assistance. This study was supported by grants from the National Nature Science Foundation of China (grant no. NSFC30600230) and the Chinese Doctoral Foundation (No. 331).

\section{References}

1. Münzel T, Feil R, Mülsch A, Lohmann SM, Hofmann F and Walter U: Physiology and pathophysiology of vascular signaling controlled by guanosine $3^{\prime}, 5^{\prime}$-cyclic monophosphate-dependent protein kinase [Corrected]. Circulation 108: 2172-2183, 2003. 
2. Ross EM and Wilkie TM: GTPase-activating proteins for heterotrimeric $\mathrm{G}$ proteins: regulators of $\mathrm{G}$ protein signaling (RGS) and RGS-like proteins. Annu Rev Biochem 69: 795-827, 2000.

3. Hollinger S and Hepler JR: Cellular regulation of RGS proteins: modulators and integrators of $\mathrm{G}$ protein signaling. Pharmaco Rev 54: 527-559, 2002.

4. Tang KM, Wang GR, Lu P, Karas RH, Aronovitz M, Heximer SP Kaltenbronn KM, Blumer KJ, Siderovski DP, Zhu Y and Mendelsohn ME: Regulator of G-protein signaling-2 mediates vascular smooth muscle relaxation and blood pressure. Nat Med 9: 1506-1512,2003.

5. Sun X, Kaltenbronn KM, Steinberg TH and Blumer KJ: RGS2 is a mediator of nitric oxide action on blood pressure and vasoconstrictor signaling. Mol Pharmacol 67: 631-639, 2005.

6. Heximer SP, Knutsen RH, Sun X, Kaltenbronn KM, Rhee MH, Peng N, Oliveira-dos-Santos A, Penninger JM, Muslin AJ, Steinberg TH, et al: Hypertension and prolonged vasoconstrictor signaling in RGS2-deficient mice. J Clin Invest 111: 1259, 2003.

7. Yang J, Kamide K, Kokubo Y, Takiuchi S, Tanaka C, Banno M, Miwa Y, Yoshii M, Horio T, Okayama A et al: Genetic variations of regulator of G-protein signaling 2 in hypertensive patients and in the general population. J Hypertens 23: 1497-1505, 2005.

8. Riddle EL, Rana BK, Murthy KK, Rao F, Eskin E, O'Connor DT and Insel PA: Polymorphisms and haplotypes of the regulator of G protein signaling-2 gene in normotensives and hypertensives. Hypertension 47: 415-420, 2006.

9. Kamide K, Kokubo Y, Yang J, Takiuchi S, Horio T, Matsumoto S, Banno M, Matayoshi T, Yasuda H, Miwa Y, et al: Association of intima-media thickening of carotid artery with genetic polymorphisms of the regulator of G-protein signaling 2 gene in patients with hypertension and in the general population. Hypertens Res 34: 740-746, 2011.

10. Kitamura K, Kangawa K, Kawamoto M, Ichiki Y, Nakamura S, Matsuo $\mathrm{H}$ and Eto T: Adrenomedullin: a novel hypotensive peptide isolated from human pheochromocytoma. Biochem Biophys Res Commun 192: 553-560, 1993.

11. Samson WK, Resch ZT, Murphy TC, Vargas TT and Schell DA: Adrenomedullin: is there physiological relevance in the pathology and pharmacology? News Physiol Sci 14: 255-259, 1999.

12. Ishiyama Y, Kitamura K, Ichiki Y, Sakata J, Kida O, Kangawa K and Eto T: Haemodynamic responses to rat adrenomedullin in anaesthetized spontaneously hypertensive rats. Clin Exp Pharmacol Physiol 22: 614-618, 1995.

13. Parkes DG and May CN: Direct cardiac and vascular actions of adrenomedullin in conscious sheep. Br J Pharmacol 120 1179-1185, 1997.

14. Hjelmqvist H, Keil R, Mathai M, Hübschle T and Gerstberger R: Vasodilation and glomerular binding of adrenomedullin in rabbit kidney are not CGRP receptor mediated. Am J Physiol 273: R716-R724, 1997.

15. Lainchbury JG, Cooper GJ, Coy DH, Jiang NY, Lewis LK, Yandle TG, Richards AM and Nicholls MG: Adrenomedullin: a hypotensive hormone in man. Clin Sci (Lond) 92: 467-472, 1997.

16. Parkes DG: Cardiovascular actions of adrenomedullin in conscious sheep. Am J Physiol 268: H2574-H2578, 1995.

17. Feng CJ, Kang B, Kaye AD, Kadowitz PJ and Nossaman BD: L-NAME modulates responses to adrenomedullin in the hindquarters vascular bed of the rat. Life Sci 55: PL433-PL438, 1994

18. Fukuhara M, Tsuchihashi T, Abe I and Fujishima M: Cardiovascular and neurohormonal effects of intravenous adrenomedullin in conscious rabbits. Am J Physiol 269: R1289-R1293, 1995.

19. Nakamura M, Yoshida H, Makita S, Arakawa N, Niinuma H and Hiramori K: Potent and long-lasting vasodilatory effects of adrenomedullin in humans. Comparisons between normal subjects and patients with chronic heart failure. Circulation 95: $1214-1221,1997$.
20. Shirai M, Shimouchi A, Ikeda S, Ninomiya I, Sunagawa K, Kangawa $\mathrm{K}$ and Matsuo $\mathrm{H}$ : Vasodilator effects of adrenomedullin on small pulmonary arteries and veins in anaesthetized cats. Br J Pharmacol 121: 679-686, 1997.

21. Champion HC, Lambert DG, McWilliams SM, Shah MK, Murphy WA, Coy DH and Kadowitz PJ: Comparison of responses to rat and human adrenomedullin in the hindlimb vascular bed of the cat. Regul Pept 70: 161-165, 1997.

22. Dieplinger B, Mueller T, Kollerits B, Struck J, Ritz E, von Eckardstein $\mathrm{A}$, Haltmayer $\mathrm{M}$ and Kronenberg $\mathrm{F}$; MMKD Study Group: Pro-A-type natriuretic peptide and pro-adrenomedullin predict progression of chronic kidney disease: the MMKD Study. Kidney Int 75: 408-414, 2009.

23. Hinson JP, Kapas S and Smith DM: Adrenomedullin, a multifunctional regulatory peptide. Endocr Rev 21: 138-167, 2000.

24. Samson WK: Proadrenomedullin-derived peptides. Front Neuroendocrinol 19: 100-127, 1998.

25. Gumusel B, Chang JK, Hyman A and Lippton H: Adrenotensin: an ADM gene product with the opposite effects of ADM. Life Sci 57: PL87-PL90, 1995.

26. Zhou L, Qiu Z, Ye C, Di L, Liu X, Tang C and Zhao Y: Vasoactive effects of adrenotensin and its interactions with adrenomedullin. Chin Med J (Engl) 113: 269-271, 2000.

27. Hitomi H, Fukui T, Moriwaki K, Matsubara K, Sun GP, Rahman M, Nishiyama A, Kiyomoto H, Kimura S, Ohmori K, Abe Y and Kohno M: Synergistic effect of mechanical stretch and angiotensin II on superoxide production via NADPH oxidase in vascular smooth muscle cells. J Hypertens 24: 1089-1095, 2006.

28. Muslin AJ: Tuning cardiomyocyte Gq signaling with RGS2. J Mol Cell Cardiol 41: 14-16, 2006.

29. Kehrl JH and Sinnarajah S: RGS2: a multifunctional regulator of G-protein signaling. Int J Biochem Cell Biol 34: 432-438, 2002.

30. Beltowski J and Jamroz A: Adrenomedullin - what do we know 10 years since its discovery? Pol J Pharmacol 56: 5-27, 2004.

31. Sato A, Canny BJ and Autelitano DJ: Adrenomedullin stimulates cAMP accumulation and inhibits atrial natriuretic peptide gene expression in cardiomyocytes. Biochem Biophys Res Commun 230: 311-314, 1997.

32. Cai Y, Teng X, Pan CS, Duan XH, Tang CS and Qi YF: Adrenomedullin up-regulates osteopontin and attenuates vascular calcification via the cAMP/PKA signaling pathway. Acta Pharmacol Sin 31: 1359-1366, 2010.

33. Takata F, Dohgu S, Nishioku T, Takahashi H, Harada E, Makino I, Nakashima M, Yamauchi A and Kataoka Y: Adrenomedullin-induced relaxation of rat brain pericytes is related to the reduced phosphorylation of myosin light chain through the cAMP/PKA signaling pathway. Neurosci Lett 449: $71-75,2009$.

34. Gumusel B, Chang JK, Hao Q, Hyman A and Lippton H: Adrenotensin: an adrenomedullin gene product contracts pulmonary blood vessels. Peptides 17: 461-465, 1996.

35. Qi YF, Bu DF, Niu DD, Shi YR, Wang SH, Pang YZ, Tang CS and Du JB: Effects of different peptide fragments derived from proadrenomedullin on gene expression of adrenomedullin gene. Peptides 23: 1141-1147, 2002.

36. Cuifen Z, Lijuan W, Li G, Wei X, Zhiyu W and Fuhai L: Changes and distributions of peptides derived from proadrenomedullin in left-to-right shunt pulmonary hypertension of rats. Circ J 72: 476-481, 2008. 